\title{
The Influence of Perceptions of Risks and Benefits on the Continuity of Use of Fintech Services
}

\author{
Artur Barretti Mascarenhas ${ }^{1}$ \\ arturmascarenhas@usp.br|(1D)0000-0002-6039-5927 \\ Cristiane Koda Perpétuo ${ }^{1}$ \\ cristiane.perpetuo@usp.br| (DD 0000-0002-0814-2076 \\ Erika Borgonovo Barrote ${ }^{1}$ \\ erika.barrote@usp.br| (10)0000-0003-4250-4488 \\ Maria Paula Perides ${ }^{1}$ \\ paula.perides@terra.com.br| (D) 0000-0002-3761-8803
}

\begin{abstract}
New technologies have been driving the global financial market, including fintech companies, which provide disruptive financial services in which information technology is the key factor. The objective of this study is to identify which factors most influence intentions to continue using these companies' products. To achieve this, research by Ryu (2018) was replicated. Our adopted model evaluates the weight of seven factors composing two latent variables - perceived risk and perceived benefit - in the continuity of use of these services. The data collection was performed through an electronic survey, distributed through social networks during May and June of 2019. The main results confirmed seven of the eleven initial hypotheses, highlighting that the perceived benefits, especially the economic ones, were relevant to early adopters and seamless transactions were relevant for late adopters. Surprisingly, perceived risk was not a determinant of continuance intention. One of the contributions of this study is that it indicates some possible demographic and behavioral characteristics of Brazilian fintech consumers, opening up space for a better understanding of the market and service improvements.
\end{abstract}

\section{KEYWORDS}

fintech, continuance intention, perceived risk, perceived benefit
${ }^{1}$ Universidade de Sáo Paulo, São Paulo, SP, Brasil

Received: $12 / 23 / 2019$.

Revised: 03/27/2020.

Accepted: 04/20/2020.

Published Online: 11/16/2020.

DOI: http://dx.doi.org/10.15728/bbr.2021.18.1.1 


\section{INTRODUCTION}

In recent decades, the world has undergone an unprecedented transformation. The huge advances in the application of digital technologies are changing the way we communicate, consume goods and services, and relate with people. The founder of the World Economic Forum, Klauss Schwab (2016), defined digital technology as being "technology based on computers, software, and communication networks." These are the so-called digital services. Such new channels and technologies may be used by different consumers, making the services cheaper and more agile, standardized, and reliable.

With the development and evolution of the traditional electronic financial services, there has been an emergence of new companies in the sector, who use technology not only as an enabler to deliver the services al ready traditionally provided, but also as an innovative tool that interrupts the value chain, ignoring the existing channels (Ryu, 2018). These are fintech companies, fintech being a term composed of "finance" and "technology," which refers to the convergence of financial services and information technology (Kim et al., 2016).

With fintechs, users can connect through a variety of mobile services, such as making payments, transferring money, requesting loans, buying insurance, managing assets, and making investments (Ryu, 2018), among others. To clearly differentiate the digital services provided by the traditional financial companies from those of these new organizations, we will, in this article, adopt Ryu's (2018) definition for fintechs as being "innovative and disruptive services provided by nonfinancial companies, where IT is the key factor."

But despite investors betting considerably on this business model, the acceptance of fintechs by consumers of financial services, as well as their continued use, remains in doubt. Some users are skeptical about using fintech services, as they think that their operations involve considerable risks (Ryu, 2018). Thus, it is essential to identify the factors that most influence people to accept or not accept the use of the financial services offered by these companies in Brazil.

Generally, consumers make decisions with incomplete or imperfect information (Kim et al., 2016), assuming a certain degree of risk, at the same time that they identify some benefits that can influence their decisions to use products and services or not. Not all consumers react in the same way, or at the same time, to these perceived factors. According to Rogers (1983), individuals can be classified into five categories, according to the speed with which they accept new technologies: innovators, early adopters, early majority, late majority, and laggards. Kim et al. (2010) simplified this classification, grouping the first three groups (innovators, early adopters, and early majority) into "early adopters," which represents consumers who like innovation and quickly accept new technologies. The last two groups (late majority and laggards) were grouped into "late adopters," representing those who are more resistant to begin using new technologies. That was the classification adopted for this article.

This study focuses on identifying both the perceived benefits as well as the perceived risk factors that influence the use of the digital financial services provided by fintech-type companies. To achieve this, the proposal is to replicate the research applied by Ryu (2018) in South Korea and his questionnaire, adapting the author's model to the Brazilian public. With this, we seek to answer the following question: what are the factors that most influence the use continuance intention of digital service consumers?

The specific objectives of this study are:

- To identify whether there is a difference between the factors that influence the behavior of early adopters and late adopters; 
- To identify which perceived benefits most influence the intention to continue using the services offered by fintechs;

- To identify which perceived risks most influence the intention to continue using the services offered by fintechs.

\section{THEORETICAL FRAMEWORK}

To advance the understanding of the factors that influence the continuity of use for fintech services, this study aims to incorporate and combine models already established by areas of knowledge focused on consumer behavior, in order to build a consolidated model that can achieve the desired objectives.

\subsection{TRA (THEORY OF REASONED ACTION)}

The Theory of Reasoned Action (TRA) is one of the most accepted theories on consumer behavior within social psychology, established by the studies of Fishbein and Ajzen (1975) and Fishbein and Ajzen (1980) to explain behavior in various contexts. For the authors, the TRA is "designed to explain virtually any human behavior" (Fishbein \& Ajzen, 1980). This theory is appropriate for studying factors that influence consumers to adopt digital services, as in this case.

According to the TRA, a person's behavior intention is a measure of the intensity of the person's intention to engage in a particular behavior as a result of two joint factors: the person's attitude in relation to the behavior and their subjective norms with regards to engaging in that behavior. The attitude factor refers to the person's emotional state - whether positive or negative - in relation to that task: people are their beliefs in regards to the subjective probability of the consequences of adopting the behavior in question. Subjective norms are subjective social norms, that is, the person's perception in relation to what their peers think in regards to that behavior. This perception is composed of their normative beliefs, that is, the expectation that people, or specific groups, have in relation to the behavior in question and by the person's motivation to fulfill those expectations.

Table 1 illustrates previous studies that have analyzed the framework of the decision-making process, when adopting or using information technology services (Shawaqfeh, 2018; Martins et al., 2014; Lee, 2009; Rahi et al., 2019; Gangwar et al., 2015; Lin et al., 2020). Most of these studies have considered perceived benefits and risks as a multidimensional concept that generally contains various types of benefits and risks.

Martins et al. (2014), for example, discuss the theory of acceptance and use of technology with the risks perceived in internet banking, emphasizing the risk of users' psychological barriers, while Rahi (2019) draws a parallel between expectations of effort and performance, also for the same segment. Ease and quality of credit are explored by Shawaqfeh (2018) in the various applications of e-commerce, reinforcing that quality of credit implies system security.

Lee (2009) proposes a theoretical model to explain intentions to use internet banking services. In this study, perceived risk was understood as a compound of factors such as security/privacy, financial risk, social risk, time/convenience, and performance risks, while perceived benefit was seen as a single construct. Gangwar et al. (2015) analyzed the benefits and risks to using cloud computing services. In this study, the authors propose six types of benefits, namely: compatibility, organizational competence readiness, managerial support, ease of use, competitiveness, and training and education) and two types of risks, which arecomplexity and security, that areassociated with the adoption of cloud computing. 
BBR

18

4

Table 1

Framework of the relationship between benefits and risks and the adoption and use of IT services

\begin{tabular}{|c|c|c|c|}
\hline Research context & Benefits & Risks & Authors \\
\hline E-commerce & $\begin{array}{l}\text { Ease of credit } \\
\text { Integration between } \\
\text { different businesses }\end{array}$ & $\begin{array}{l}\text { Lack of awareness of all } \\
\text { the applications }\end{array}$ & Shawaqfeh (2018) \\
\hline Internet Banking & $\begin{array}{l}\text { Diversification of services } \\
\text { Greater security } \\
\text { Quality of transactions } \\
\text { Financial benefit } \\
\text { Speed of transactions } \\
\text { Information } \\
\text { Transparency }\end{array}$ & $\begin{array}{l}\text { Psychological barriers } \\
\text { Equipment costs } \\
\text { Security/privacy } \\
\text { Financial } \\
\text { Social } \\
\text { Convenience } \\
\text { Performance }\end{array}$ & $\begin{array}{l}\text { Martins et al. (2014), } \\
\text { Lee (2009), } \\
\text { Rahi et al. (2019), } \\
\text { Shawaqfeh (2018) }\end{array}$ \\
\hline Cloud Computing & $\begin{array}{l}\text { Compatibility } \\
\text { Organizational } \\
\text { competency readiness } \\
\text { Managerial support } \\
\text { Ease of use } \\
\text { Competitiveness } \\
\text { Training and education }\end{array}$ & $\begin{array}{l}\text { Complexity } \\
\text { Security }\end{array}$ & Gangwar et al. (2015) \\
\hline Mobile Payment & $\begin{array}{l}\text { Compatibility of services } \\
\text { Relative advantage } \\
\text { Social influence }\end{array}$ & $\begin{array}{l}\text { Perceived cost } \\
\text { Security } \\
\text { Social influence }\end{array}$ & Lin et al. (2020) \\
\hline
\end{tabular}

Lin et al. (2020) investigate the antecedents of the use of mobile payment services, these perspectives being based on the theory on the relationship between cost and benefit, perceived value, and social influences. As perceived benefits, the authors propose relative advantages, compatibility of services, and social influence, and, as perceived costs, the authors propose security and transaction costs.

\subsection{Net Valence}

Combining perceived benefits and risks, Peter and Tarpey (1975) provided a model called the Net Valence model, assuming that consumers perceive products or services as having positive and negative attributes and make decisions to maximize the valence derived from accepting them.

Specifically, the benefits and risks of using fintechs can be considered according to personal beliefs (positive or negative) that determine attitudes and, later, behavioral intentions and actions (Jurison, 1995).

The Net Valence model addresses the consumer's perception with regards to the risks and benefits of a product or service to be used as factors that influence their acceptance. This model is based on the original theory called the Theory of Reasoned Action (TRA) (Fishbein \& Ajzen, 1980) previously addressed in this article. 


\subsection{Model FOR ANALYZING RISKS AND BENEFITS OF USING FINTECHS}

Based on the TRA and Net Valence models, the intention to continue using the products and services of fintechs would depend on the user's perception as it relates to their use, given that it is influenced by behavioral beliefs. In 2018, Hyun-Sun Ryu proposed a model based on those theories to evaluate the factors that make the user willing or hesitant to use thea fintech's services.

In that model, three types of benefits were addressed: economic benefit, such as the reduction of costs or financial advantages derived from using fintech services; ease of transactions, related to the speed and simplicity of the transactions carried out by fintechs; and convenience, such as the possibility of using fintech services anywhere, at any time of the day. Four types of risks are also addressed: financial, such as the potential for financial loss from using fintechs; legal, such as the legal insecurity resulting from the lack of fintech regulations; security, such as the potential financial loss from fraud or cybernetic attacks that compromise the security of fintech transactions; and operational, such as the potential financial loss resulting from problems in internal processes or the insolvency of a fintech. Figure 1 shows the model proposed and applied by Ryu (2018), which establishes all the hypotheses to be tested in this study.

The proposed model considers that the perception of the benefits and risks obtained through the use of fintechs influence the consumer's intention to continue using this type of service. The perceived benefits are expected to have a positive influence on the intention to continue using fintechs. On the other hand, the perceived risks should negatively influence this same continuance intention.

We thus establish the first hypotheses of the model to be tested:

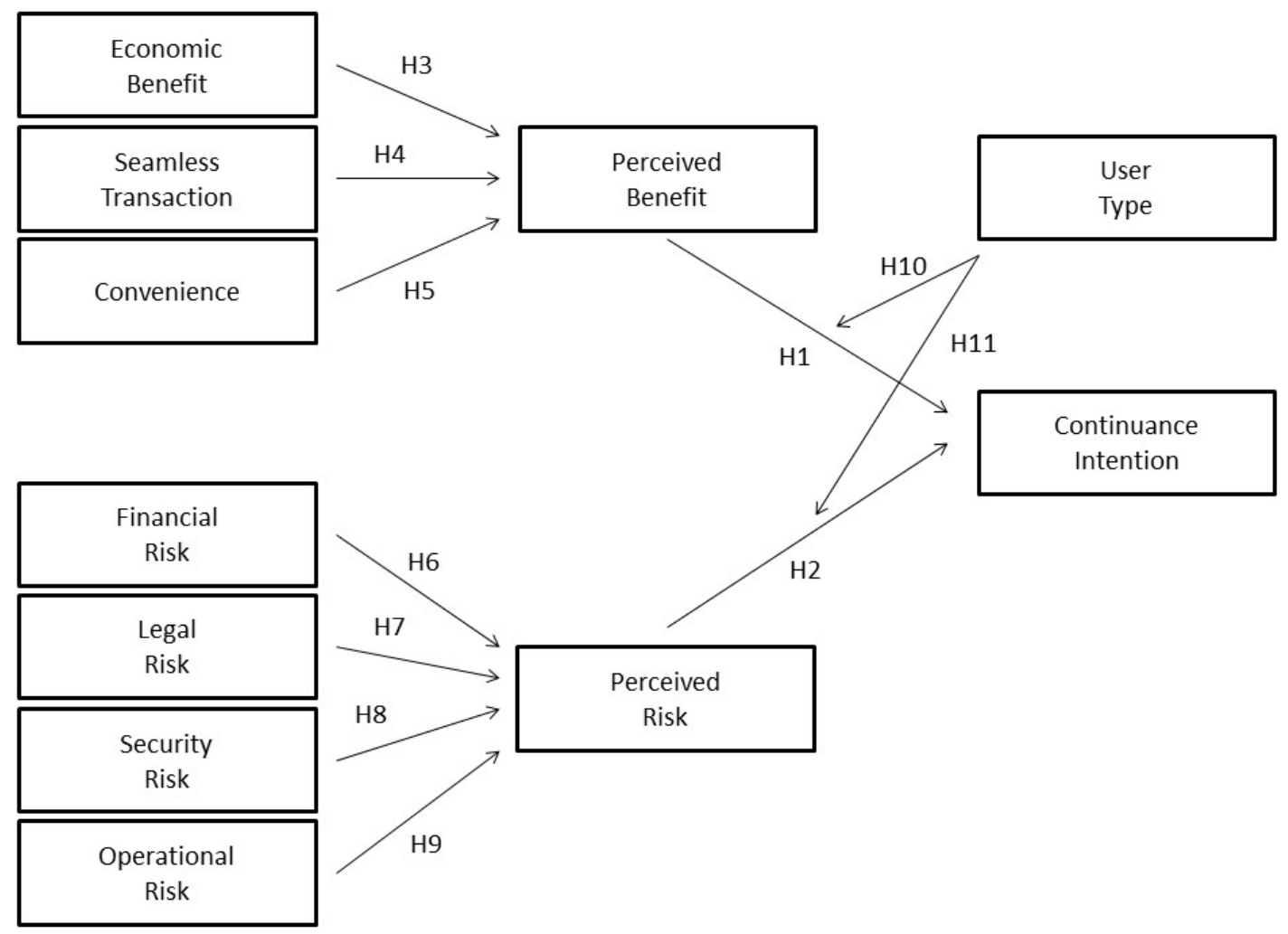

Figure 1. Theoretical research model from Ryu (2018).

Source: Ryu (2018). 
- H1: The perceived benefit is positively related to the intention to continue using the digital services offered by fintechs.

- H2: The perceived risk is negatively related to the intention to continue using the digital services offered by fintechs.

\subsubsection{Benefit factors for continued use of fintechs}

Users' motivations have been classified as extrinsic and intrinsic factors by Cognitive Evaluation Theory (Davis et al., 1989). This study proposes three motivations as the components of perceived general benefit: economic benefit, seamless transactions, and convenience. Economic benefit is the most common and most consistent motivation for fintechs (Lee \& Teo, 2015). Economic benefit includes cost reductions and financial gains from transactions.

Some fintech applications may suggest cheaper transaction costs for users, compared with traditional financial service providers, directly supplying standardized services through a mobile services platform without intermediation (Mackenzie, 2015). Other applications of fintechs, which generally offer services online or via a mobile platform, may also provide higher returns to creditors, and lower interest rates for borrowers, than traditional financial institutions, using platforms with lower indirect costs (Gerber et al., 2012; Lee \& Lee, 2012).

Seamless transactions refers to the benefits related to transactions using a fintech that eliminates traditional financial institutions, enabling users to manage transactions on economic platforms, resulting in simpler and quicker financial operations (Chishti, 2016; Zavolokina et al., 2016a). Moreover, non-financial providers (that is, IT companies) may create and offer innovative, userfriendly financial products and services to customers, as they supply their products and services directly.

Convenience is one of the motivations driven by immediate portability and accessibility (Lee \& Teo, 2015; Sharma \& Gutierrez, 2010). Convenience refers to flexibility in time and location (Okazaki \& Mendez, 2013), the most important factor in the success of online and mobile services (Kim et al., 2010). Users can acquire convenience and efficiency without precedents through mobile devices without physically going to financial institutions. The relationships between the aforementioned factors and the benefits perceived by the fintech user will be tested by the following hypotheses:

- H3: Economic benefit is positively related to perceived benefit.

- H4: Seamless transactions is positively related to perceived benefit.

- H5: Convenience is positively related to perceived benefit.

\subsubsection{Risk factors for continued use of fintechs}

Besides the perceived benefits, innovation generally comes with risks (Schierz et al., 2010). As fintech services are emerging services without precedents, their users are vulnerable to wideranging risks.

Cunningham (1967) categorized perceived risk into six dimensions: performance, financial consideration, opportunity/time, security, social factors, and psychological factors. When transferring that structure to the context of fintechs, this study uses the following four types of risks as perceived risk factors: financial, legal, security, and operational risks. 
Financial risk refers to the potential financial loss from conducting financial transactions with fintechs (Forsythe et al., 2006). The financial losses of fintechs, caused by the poor functioning of the system of financial transactions, financial fraud, moral risk, and extra transaction fees associated with the price of early adoption (World Economic Forum, 2015; Zavolokina et al., 2016b), are negatively related with the continuance use intention. Legal risk refers to the uncertainty of the legal situation and the lack of regulations for fintechs. As the fintech industry has no precedents in the market, the lack of regulation regarding financial losses or security problems can result in anxiety or distrust on the part of the user (Ryu, 2018). Security risk is defined as possible loss from fraud or invasion by hackers compromising the security of financial transactions. Fintech use is associated with a relatively high potential loss (that is, involving privacy, personal data, and transactions) (Schierz et al., 2010). This also increases the perceived risk. Operational risk is a critical barrier for users, since many important operational losses have affected large financial institutions, leading to the serious financial disruption or collapse of these institutions. Operational risk refers to potential loss due to internal processes, employees, and inadequate or faulty systems (Barakat \& Hussainey, 2013). If the risk probabilities of the company's financial systems and operations are high, the users will not continue using the fintech. A lack of operational abilities and immediate responses, the poor functioning of systems, and inadequate internal processes will result in user distrust and dissatisfaction, leading to a deterrent to the use of fintechs.

Due to the perceived risks, users will make usage decisions based on the good reputation of financial technology companies in terms of operational abilities and advanced systems. Consequently, the three types of risks can significantly affect the perceived general risk, negatively influencing the intention to continue using fintechs. The influence of the risk factors mentioned in relation to the risk perceived by fintech users can be tested by the following hypotheses:

- H6: Financial risk is positively associated with perceived risk.

- H7: Legal risk is positively associated with perceived risk.

- Hs: Security risk is positively associated with perceived risk.

- H9: Operational risk is positively associated with perceived risk.

\subsection{USER TYPE AND THE MODERATION EFFECT}

When an innovation is launched onto the market, not all individuals in that society adopt it simultaneously. The period that each one takes to adopt that innovation can vary due to several factors. Rogers (1983) classified individuals into five categories, according to the time that each one takes to start using a particular innovation. They are: innovators, early adopters, early majority, late majority, and laggards. From studying factors that influence users to adopt mobile payment systems, Kim et al. (2010) proposed a simplification of that model, dividing the sample of users into early adopters and late adopters. In this study, we will adopt the model proposed by Kim et al. (2010), dividing the survey respondents into early and late adopters.

Previous empirical studies (Escobar-Rodríguez \& Romero-Alonso, 2014; Hong \& Zhu, 2006; Kim et al., 2010) show that early adopters are individuals interested in adopting new technologies or services and are willing to take risks. Late adopters are more reserved and skeptical people in regards to adopting new technologies or services.

The distinctions between early and late adopters in the financial sector are more significant than in other sectors. A comparison of the characteristics of early and late adopters may provide 


\section{METHODOLOGY}

The research we conducted is considered to be quantitative, descriptive, and correlational. The research phenomena were observed, recorded, analyzed, and correlated without there being any manipulation of them (Cervo et al., 2007). The research method we used was a survey, where the desired data and information were obtained using a pre-defined research instrument, normally a questionnaire (Freitas et al., 2000).

A pre-test was carried out with eight respondents and the result obtained resulted in the removal of one of the questions, which was considered redundant, and indicated the need to alter the wording of three questions, making them clearer. The first question chose the respondents, guaranteeing they had all used some fintech service.

Next, each one of the hypotheses were evaluated with three to four questions, following the model previously used by Ryu (2018), with a seven-point Likert scale, where 1 (one) means "totally disagree" and 7 (seven) means "totally agree."

At the end, nine additional demographic and informative questions were added, with the intention of understanding the characteristics of the population of respondents in relation to sex, age group, individual income range, educational level, region of the country where they live, time using the services in question, and, finally, whether the respondent also uses traditional banks. The questionnaire for the data collection was elaborated in the TypeForm tool and the corresponding link was sent to the participants. The sample was chosen by convenience, on the social networks of the authors and from the list of the institution (FEA-USP), including respondents from all regions of the country, with the greatest concentration in the Southeast region, as observed in Table 2.

The answers obtained covered a total of 181 respondents, 155 of which were fintech users, composing a percentage of $85.64 \%$ valid participants. Table 2 illustrates the characteristics of the sample. It is observed that there was a balance between male and female respondents, with the majority being between 16 and 45 years old, having a complete college education or post-graduate degree, a level of income above $\mathrm{R} \$ 4,401.00$, and residing in the Southeast or South regions. The sample presents a certain homogeneity in relation to income and frequency of fintech use.

In this study, the PLS methods were adopted to test the proposed model and its hypotheses, and decision tree and clusters analyses were employed, to discover the patterns of fintech user profiles for predicting which public has the greatest intention to continue using fintech services. The PLS method is recommended for predictive research models, with an emphasis on theory development (Hair Jr. et al., 2014). Given that this study is an attempt to make advances in the theoretical model that determines the benefit and risk factors that influence behavioral intentions in relation to fintechs, this method was chosen due to its suitability to exploratory science (Hair Jr. et al., 2014). For the analysis, the Smart PLS version 3.0 software was used. 
Table 2

Demographic characteristics of the sample

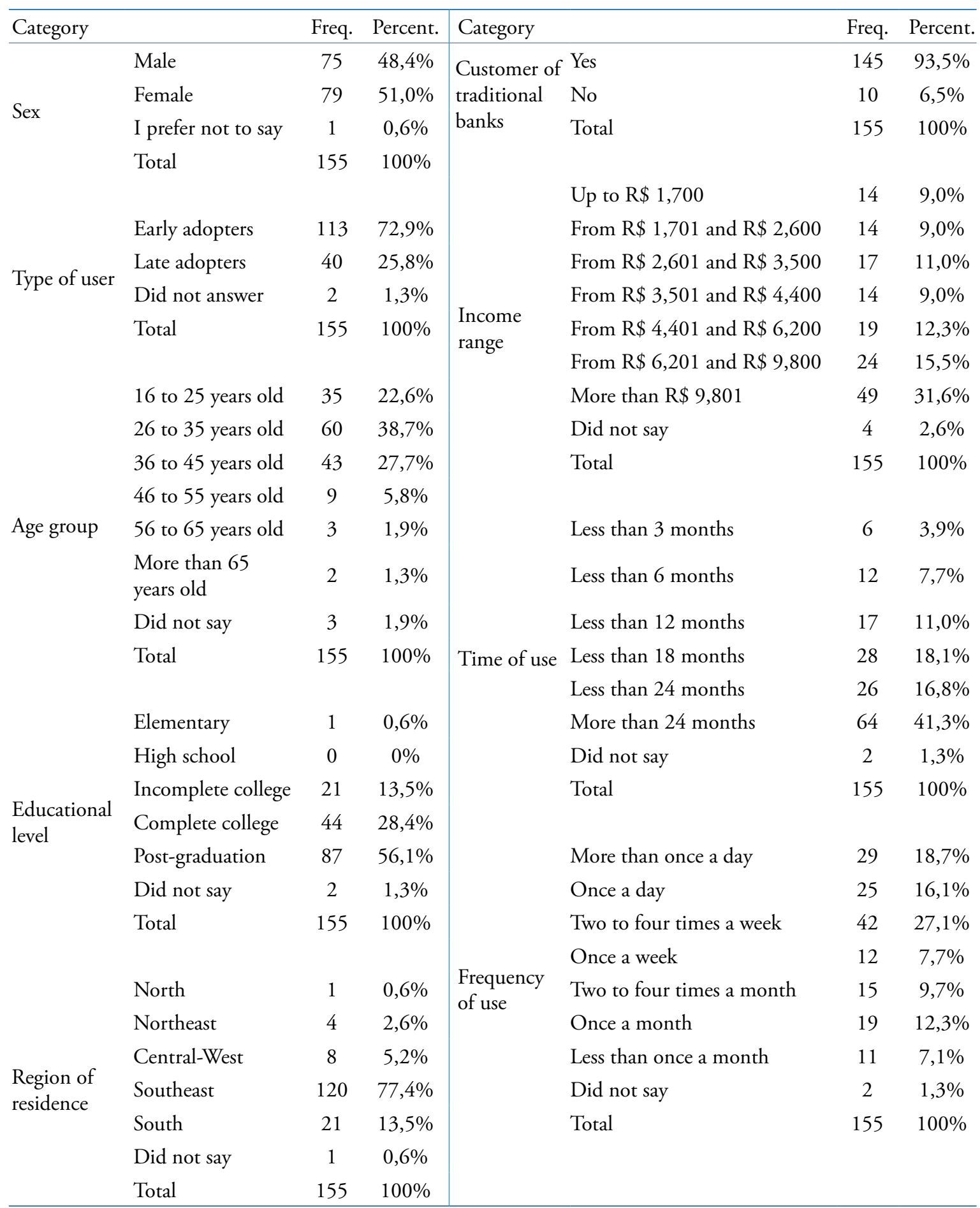


Due to the exploratory character of this research, cluster and decision tree analyses were carried out (Oliveira, 2004). For both analyses, the RStudio software and the CAR, C5.0, and cluster libraries were used. The decision tree is a technique used for evaluating various alternatives, by calculating the expected value for each alternative, presenting, as its main advantage, the compilation of compact structures and high legibility, so that its results are easily understandable (Halmenschlager, 2002).

The cluster analysis, also known as conglomerates analysis, was introduced by Tyron (I939). The procedures used in the cluster analysis can be hierarchical or non-hierarchical, and aim to group subjects or variables into homogenous groups based on one or more common characteristics (Maroco, 20I4).

\section{ANALYSIS AND DISCUSSION OF THE RESULTS}

In order to analyze the influences of behavioral and demographic factors on the intention to continue using the services offered by fintechs, as well as carrying out tests of the hypotheses proposed by this study, three types of analysis were used: decision tree, conglomerates, and PLS .

\subsection{Decision Trees}

In the decision tree analysis, the aim was to discover the patterns of the fintech user profiles in order to predict which public has the greatest intention to continue using this type of service.

According to the results of the research based on the decision tree analysis, decision trees were generated for each one of the factors perceived in the theoretical model and the demographic variables (sex, age group, income range, use of financial services of traditional banks, time of use, and region). Table 3 presents the results of the analysis, showing which demographic variables were most used for each factor of the model.

From analyzing the perceived benefit factor and the perceived risk factor separately in relation to the demographic variables it can be concluded that the most representative attributes in the classification of the tree were age, income range, and time of use for perceived benefit and, for perceived risk, the most significant attributes were region, time of use, and age. Similarly, for the continuance intention factor we can concluce that the most significant attributes for the classification of the tree were income range, region, and time of use.

\subsection{Conglomerates}

According to the results of the research based on the conglomerates analysis conducted in the RStudio software, using the Ward method and Euclidian distance, it was noted that separation into 3 clusters best produces homogenous groups internally, and heterogeneous ones among each other. The conglomerates analysis generated the following clusters reported in Table 4 with the percentages of their predominant variables.

From analyzing cluster 1 , we found that the percentages of the predominant variables are, respectively: income range above $\mathrm{R} \$ 9800$ (4.1\%); residents in the Central-West region (5.41\%), followed by the Northeast region (2.70\%); time of use of less than 2 years $(2.03 \%)$ and more than 2 years $(2.70 \%)$; age group between 26 and 35 years old $(4.05 \%)$ and between 35 and 45 years old (3.38\%); male (3.38\%) and female (4.73\%); post-graduate educational level (6.67\%). 
Table 3

Results of the decision tree analysis

\begin{tabular}{|c|c|c|c|c|c|}
\hline \multicolumn{2}{|l|}{ Category } & \multirow{2}{*}{$\begin{array}{c}\text { Percent. } \\
97,4 \%\end{array}$} & \multicolumn{2}{|l|}{ Category } & \multirow{2}{*}{$\begin{array}{l}\text { Percent. } \\
100,0 \%\end{array}$} \\
\hline \multirow{3}{*}{$\begin{array}{l}\text { Continuance } \\
\text { Intention }\end{array}$} & Income Range & & \multirow{3}{*}{$\begin{array}{l}\text { Percevied } \\
\text { Risk }\end{array}$} & Region & \\
\hline & Region & $85,8 \%$ & & Time of Use & $98,7 \%$ \\
\hline & Time of Use & $84,5 \%$ & & Age & $76,2 \%$ \\
\hline \multirow{3}{*}{$\begin{array}{l}\text { Perceived } \\
\text { Benefit }\end{array}$} & Age & $98,1 \%$ & \multirow{3}{*}{$\begin{array}{l}\text { Financial } \\
\text { Risk }\end{array}$} & Age & $98,1 \%$ \\
\hline & Income Range & $72,3 \%$ & & Educational Level & $89,0 \%$ \\
\hline & Time of Use & $66,5 \%$ & & Time of Use & $85,2 \%$ \\
\hline \multirow{3}{*}{$\begin{array}{l}\text { Economic } \\
\text { Benefit }\end{array}$} & Region & $100,0 \%$ & \multirow{3}{*}{$\begin{array}{l}\text { Security } \\
\text { Risk }\end{array}$} & Time of Use & $98,7 \%$ \\
\hline & Sex & $92,3 \%$ & & Age & $98,1 \%$ \\
\hline & Income Range & $73,6 \%$ & & Income Range & $60,0 \%$ \\
\hline \multirow{3}{*}{$\begin{array}{l}\text { Seamless } \\
\text { Transactions }\end{array}$} & Region & $100,0 \%$ & \multirow{3}{*}{$\begin{array}{l}\text { Legal } \\
\text { Risk }\end{array}$} & Traditional Bank Use & $98,7 \%$ \\
\hline & Traditional Bank Use & $80,0 \%$ & & Region & $93,6 \%$ \\
\hline & Sex & $74,8 \%$ & & Educational Level & $78,7 \%$ \\
\hline \multirow{3}{*}{ Convenience } & Time of Use & $98,7 \%$ & \multirow{3}{*}{$\begin{array}{l}\text { Operational } \\
\text { Risk }\end{array}$} & Region & $100,0 \%$ \\
\hline & Age & $75,5 \%$ & & Traditional Bank Use & $85,2 \%$ \\
\hline & Income Range & $14,8 \%$ & & Time of Use & $80,7 \%$ \\
\hline
\end{tabular}

Table 4

Clusters and their predominant variables

\begin{tabular}{|c|c|c|c|c|c|c|c|c|}
\hline \multicolumn{3}{|c|}{ Cluster 1} & \multicolumn{3}{|c|}{ Cluster 2} & \multicolumn{3}{|c|}{ Cluster 3} \\
\hline $\begin{array}{l}\text { Income } \\
\text { Range }\end{array}$ & $\begin{array}{l}\text { More than } \\
\mathrm{R} \$ 9,801\end{array}$ & $4,1 \%$ & $\begin{array}{l}\text { Income } \\
\text { Range }\end{array}$ & $\begin{array}{l}\mathrm{R} \$ 2,601 \text { to } \\
\mathrm{R} \$ 3,500\end{array}$ & $9,5 \%$ & $\begin{array}{l}\text { Income } \\
\text { Range }\end{array}$ & $\begin{array}{l}\text { More than } \\
\mathrm{R} \$ 9,801\end{array}$ & $27,0 \%$ \\
\hline Age Group & $\begin{array}{l}26 \text { to } 35 \\
\text { years old }\end{array}$ & $4,1 \%$ & Age Group & $\begin{array}{l}16 \text { to } 25 \\
\text { years old }\end{array}$ & $20,3 \%$ & Age Group & $\begin{array}{l}36 \text { to } 45 \\
\text { years old }\end{array}$ & $23,0 \%$ \\
\hline $\begin{array}{l}\text { Region of } \\
\text { Residence }\end{array}$ & $\begin{array}{l}\text { Central- } \\
\text { West }\end{array}$ & $4 \%$ & $\begin{array}{l}\text { Region of } \\
\text { Residence }\end{array}$ & Southeast & $32,4 \%$ & $\begin{array}{l}\text { Region of } \\
\text { Residence }\end{array}$ & Southeast & $46,0 \%$ \\
\hline Time of Use & $\begin{array}{l}\text { More than } \\
24 \text { months }\end{array}$ & $7 \%$ & Time of Use & $\begin{array}{l}\text { More than } \\
24 \text { months }\end{array}$ & $16,2 \%$ & $\begin{array}{l}\text { Time of } \\
\text { Use }\end{array}$ & $\begin{array}{l}\text { More than } \\
24 \text { months }\end{array}$ & $23,7 \%$ \\
\hline Sex & Female & $7 \%$ & Sex & Female & $21,0 \%$ & Sex & Male & $27,7 \%$ \\
\hline $\begin{array}{l}\text { Educational } \\
\text { Level }\end{array}$ & $\begin{array}{l}\text { Post- } \\
\text { graduation }\end{array}$ & $6,8 \%$ & $\begin{array}{l}\text { Educational } \\
\text { Level }\end{array}$ & $\begin{array}{l}\text { Complete } \\
\text { college }\end{array}$ & $16,2 \%$ & $\begin{array}{l}\text { Educational } \\
\text { Level }\end{array}$ & $\begin{array}{l}\text { Post- } \\
\text { graduation }\end{array}$ & $40,5 \%$ \\
\hline
\end{tabular}

With relation to cluster 2 , it can be observed that the percentages of the predominant variables are, respectively: income range between $\mathrm{R} \$ 2601$ and $\mathrm{R} \$ 3500$ (9.64\%), followed by the income range $\mathrm{R} \$ 4401$ to $\mathrm{R} \$ 6200$ (8.78\%); residents in the Southeast region (32.43\%), followed by the South region (6.76\%); time of use of less than 18 months (10.14\%) and more than 2 years (16.22\%); age group between 16 and 25 (20.27\%) and between 26 and 35 (16.68\%); male (18.24\%) and female (20.95\%); complete college education (12.84\%) and complete high school education (16.22\%).

Finally, it can be observed that, in cluster 3 , the percentages of the predominant variables are, respectively: income range between $R \$ 6201$ and $R \$ 9800$ (14.19\%), followed by an income above R 9801 (27.03\%); residents were in the Southeast region (45.95\%), followed by the South 
BBR

18

12

region (6.08\%); time of use was of less than 2 years $(9.64 \%)$ and more than 2 years $(23.65 \%)$; age group was between 26 and 35 (18.92\%) and between 26 and 45 (22.97\%); male (27.70\%) and female (25\%); complete college education (12.16\%) and post-graduate degree (40.54\%). Figure 2 represents the three clusters with their respective users of fintech services based on the demographic variables as previously described in the methodology.

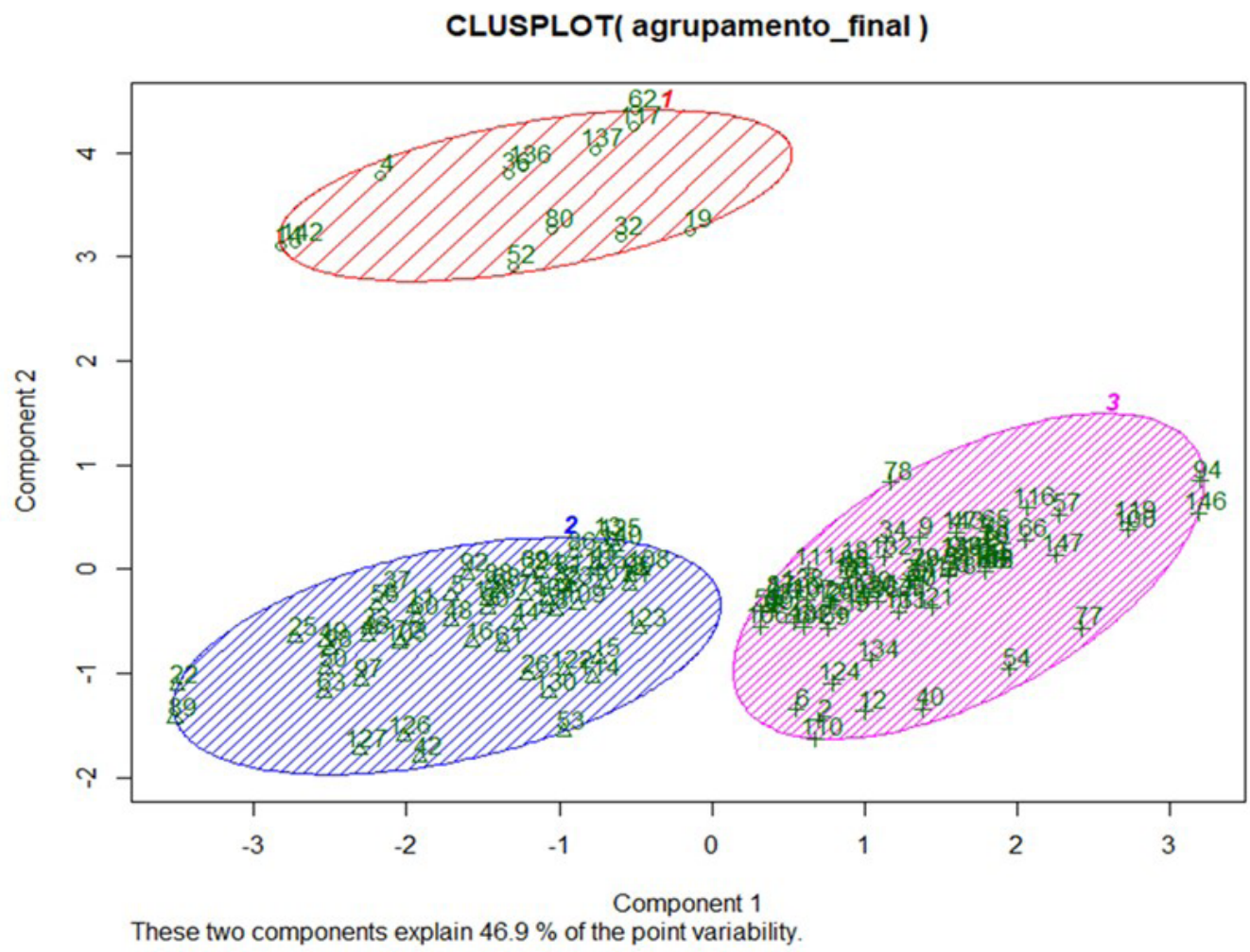

Figure 2. Clusters of respondents.

\subsection{PLS ANALYsis}

\subsubsection{Measurement Model}

To validate the measurement model of this study, four criteria were considered that measure the reliability, validity, and understanding of the items of the survey by the respondents: Cronbach's alpha, outer loadings, composite reliability (CR), and average variance extracted (AVE). According to Hair Jr. et al. (2014), the reliability of the items can be analyzed via their factor loadings, which should have a value higher than 0.7 . The PR3, SR2, LR1, and OR3 items did not reach the value suggested. However, we chose not to exclude these items as, when their exclusions were tested, there was no increase in the composite reliability of their respective factors. 
To analyze the internal consistency of the variables, the composite reliability criterion was used, as well as the Cronbach's alpha. For the first criterion, the desired values are between 0.7 and 0.95 (Hair Jr. et al., 2014), and the model was successful as it presented values between 0.804 and 0.929 . For the Cronbach's alpha, it is desirable to obtain values above 0.7 , where values above 0.6 are acceptable for empirical models (Hair Jr. et al., 2014), which was achieved by the model.

Finally, to analyze the validity of the questionnaire (Table 5), the AVE criterion was used, which, according to Hair Jr. et al. (2014), should be above 0.5 . This was achieved by the model.

Table 5

Validity of the questionnaire

\begin{tabular}{|c|c|c|c|c|c|c|c|c|c|c|c|}
\hline Constructs & Items & $\begin{array}{c}\text { Outer } \\
\text { Loadings }\end{array}$ & $\alpha$ & $\mathrm{CR}$ & AVE & Constructs & Items & $\begin{array}{c}\text { Outer } \\
\text { Loadings }\end{array}$ & $\alpha$ & CR & $\mathrm{AVE}$ \\
\hline \multirow{5}{*}{$\begin{array}{l}\text { Continuance } \\
\text { Intention }\end{array}$} & CI1 & 0,900 & 0,896 & 0,929 & 0,766 & \multirow{3}{*}{ Convenience } & CV1 & 0,912 & 0,874 & 0,914 & 0,727 \\
\hline & $\mathrm{CI} 2$ & 0,770 & \multirow{7}{*}{0,853} & \multirow{7}{*}{0,901} & \multirow{7}{*}{0,695} & & CV2 & 0,769 & & & \\
\hline & $\mathrm{CI} 3$ & 0,924 & & & & & CV3 & 0,888 & & & \\
\hline & $\mathrm{CI} 4$ & 0,898 & & & & \multirow{3}{*}{$\begin{array}{l}\text { Financial } \\
\text { Risk }\end{array}$} & FR1 & 0,723 & 0,695 & 0,830 & 0,620 \\
\hline & PB1 & 0,796 & & & & & FR2 & 0,844 & & & \\
\hline \multirow{3}{*}{$\begin{array}{l}\text { Perceived } \\
\text { Benefit }\end{array}$} & PB2 & 0,866 & & & & & FR3 & 0,790 & & & \\
\hline & PB3 & 0,898 & & & & \multirow{4}{*}{ Security Risk } & SR1 & 0,891 & 0,705 & 0,804 & 0,510 \\
\hline & PB4 & 0,768 & & & & & $\mathrm{SR} 2$ & 0,514 & & & \\
\hline \multirow{3}{*}{$\begin{array}{l}\text { Perceived } \\
\text { Risk }\end{array}$} & PR1 & 0,866 & \multirow[t]{3}{*}{0,735} & \multirow[t]{3}{*}{0,851} & \multirow[t]{3}{*}{0,657} & & SR3 & 0,879 & & & \\
\hline & PR2 & 0,869 & & & & & LR1 & 0,562 & 0,670 & 0,817 & 0,611 \\
\hline & PR3 & 0,684 & & & & \multirow{3}{*}{ Legal Risk } & LR2 & 0,699 & & & \\
\hline \multirow{4}{*}{$\begin{array}{l}\text { Economic } \\
\text { Benefit }\end{array}$} & EB1 & 0,853 & \multirow[t]{3}{*}{0,815} & \multirow[t]{3}{*}{0,890} & \multirow[t]{3}{*}{0,729} & & LR3 & 0,799 & & & \\
\hline & $\mathrm{EB} 2$ & 0,846 & & & & & LR4 & 0,773 & & & \\
\hline & EB3 & 0,863 & & & & \multirow{4}{*}{$\begin{array}{l}\text { Operational } \\
\text { Risk }\end{array}$} & OR1 & 0,829 & 0,651 & 0,811 & 0,594 \\
\hline & $\mathrm{ST} 1$ & 0,808 & \multirow[t]{3}{*}{0,662} & \multirow[t]{3}{*}{0,816} & \multirow[t]{3}{*}{0,596} & & OR2 & 0,862 & & & \\
\hline \multirow{2}{*}{$\begin{array}{l}\text { Seamless } \\
\text { Transactions }\end{array}$} & ST2 & 0,735 & & & & & OR3 & 0,593 & & & \\
\hline & ST3 & 0,772 & & & & & & & & & \\
\hline
\end{tabular}

The final analysis was the discriminant validity (DV) calculation using the Fornell-Larcker criterion (Table 6), which compared the square root of the AVE values of each factor with the correlation between the factors: for each factor, the square root of the AVE of each factor, present on the diagonal of the table below, should be greater than the factors presented in their column (Hair Jr. et al., 2014). In this case, there was a problem in the test, as the continuance intention and perceived benefit factors present a possible multicollinearity problem. However, the following tests did not present improvements in the model and, as the other validity and consistency factors presented good results, we decided to keep the proposed model.

\subsubsection{Hypotheses Tests}

All the hypotheses were tested via the PLS analysis. The path coefficients, $t$ statistics, and coefficients of determination $\left(\mathrm{R}^{2}\right)$ were used to test the structural model. The significance tests of all the path coefficients were obtained using the PLS bootstrapping resampling procedure. The proposed model is responsible for $77 \%$ of the variance in the intention to continue using fintechs. 
BBR

18

14
Table 6

Discriminant validity analysis

Figure 3 shows the path coefficients, where two of these - perceived risk and security risk were rejected by the significance test. This demonstrates that the model does not enable us to conclude that the respondents consider security risk to be significant as a perceived risk factor. Moreover, we cannot conclude that the respondents consider the perception of risk to influence the intention to continue using fintech services.

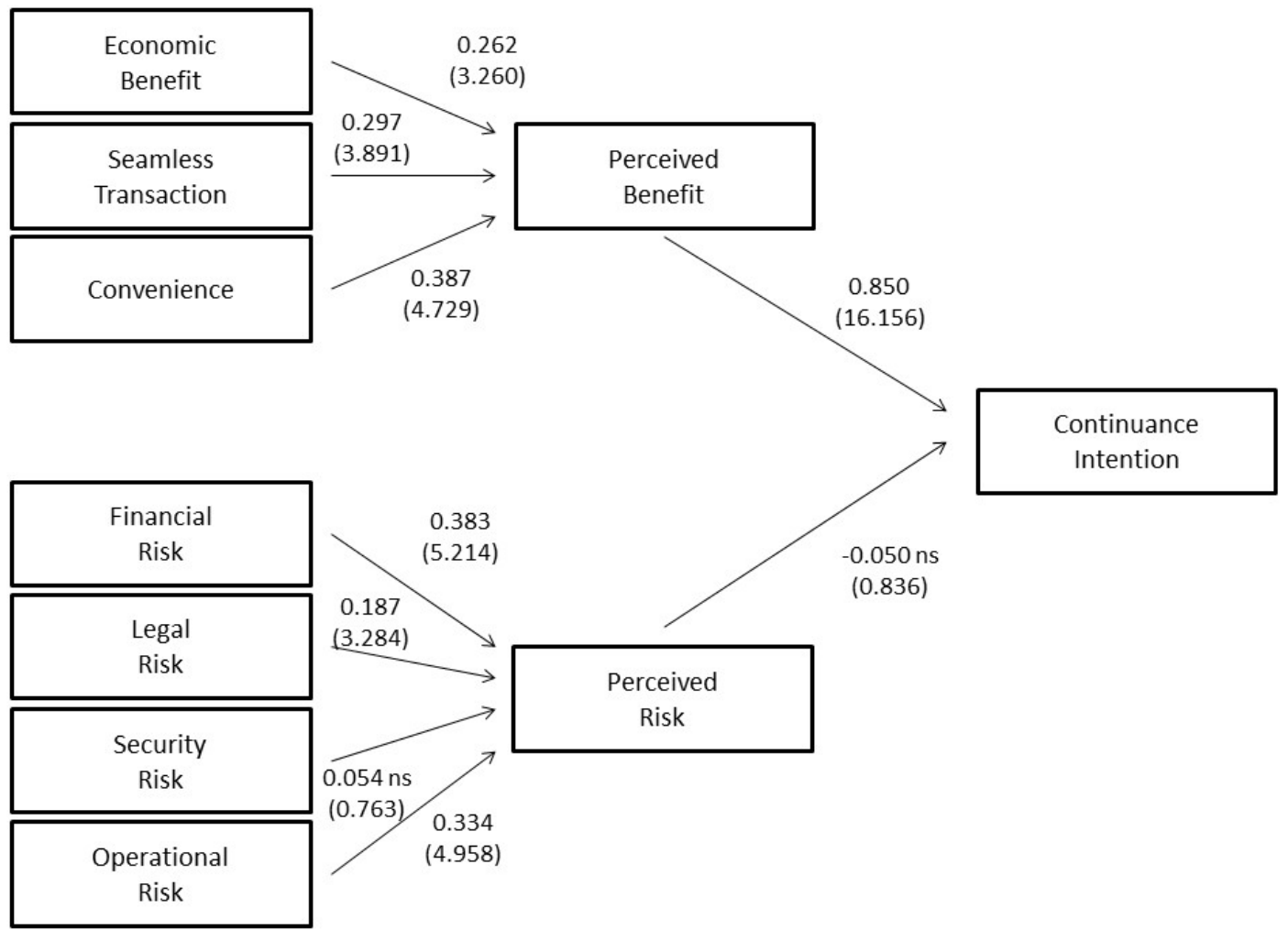

Figure 3. Perceived risks and benefits. 
Figure 3 shows that the perceived benefit factor has a significant positive effect on the intention to continue using fintechs $(\beta=0.850, \mathrm{p}<0.05)$, thus $\mathrm{H} 1$ was accepted. Perceived risk had the expected negative effect $(\beta=-0.050, \mathrm{p}>0.05)$, but it was not significant, so $\mathrm{H} 2$ should be rejected. The acceptance of $\mathrm{H} 1$, and the rejection of $\mathrm{H} 2$, may suggest that fintech users predominantly consider factors linked to the benefits accruing from the use of fintech services over the factors related to the risks of this type of service.

The factors relating to perceived benefit - economic benefit, seamless transactions, and convenience - had positive effects $(\beta=0.262, \mathrm{p}<0.05 ; \beta=0.297, \mathrm{p}<0.05 ; \beta=0.387, \mathrm{p}<0.05)$, giving support to $\mathrm{H} 3, \mathrm{H} 4$, and $\mathrm{H} 5$ being accepted. From the values of the coefficients, it can be deduced that convenience is the factor that most influences the perceived benefit, followed by seamless transactions and economic benefit, suggesting that questions linked to locational flexibility and time of use are more important than questions linked to the absence of intermediaries between customers and financial products, and questions linked to financial gains.

In relation to the factors related to perceived risks - economic risk, legal risk, security risk, and operational risk - there was the expected positive influence, that is, positively influencing the perceived risk. For the economic, legal, and operational risk factors $(\beta=0.383, p<0.05 ; \beta=0.187$, $\mathrm{p}<0.05 ; \beta=0.334, \mathrm{p}<0.05)$ there was statistical significance, supporting the acceptance of H6, H7, and H9. The security risk factor was not statistically significant $(\beta=0.054, p>0.05)$, so H8 was rejected, demonstrating that possible fraud events or the compromising of the system by external sources, such as hackers, did not influence the respondents in their perception of risk. Among the factors present in the model, the economic risk factor has the greatest effect over perceived risk, followed by operational risk and legal risk, suggesting that the aversion to financial losses overrides questions related to risks of a technical functioning or regulatory nature.

\subsubsection{Moderating effect of user types}

The fintech users were classified into two different types - early and late - based on the answers to the questionnaire that involved adoption of new technologies. According to Kim et al. (2010), the affirmations presented in Table 7 can be used to classify fintech users into two categories. Based on their answers, the respondents were classified into early and late adopters.

Table 7

Affirmations regarding each type of user

\begin{tabular}{ll}
\hline User Type & \multicolumn{1}{c}{ Affirmations } \\
\hline \multirow{2}{*}{ Early adopter } & I am willing to take risk \\
& I am interested in new technology \\
& I tend to be first in using new products and services \\
\hline Late adopter & I am hesitant to take risks \\
& I still worry about new technologies \\
& I tend to continue using existing products and services \\
\hline
\end{tabular}


BBR

18

16

The result of the classification allocated $72.9 \%$ of the respondents as early adopters and $25.8 \%$ as late adopters (1.3\% of the respondents did not answer these questions). The demographic differences between the two groups can be observed in Table 8.

For each one of the groups, a PLS analysis was carried out with the moderating variable "user type" (Hair Jr. et al., 2014), as according to the results presented in Table 9.

Table 8

Demographic data

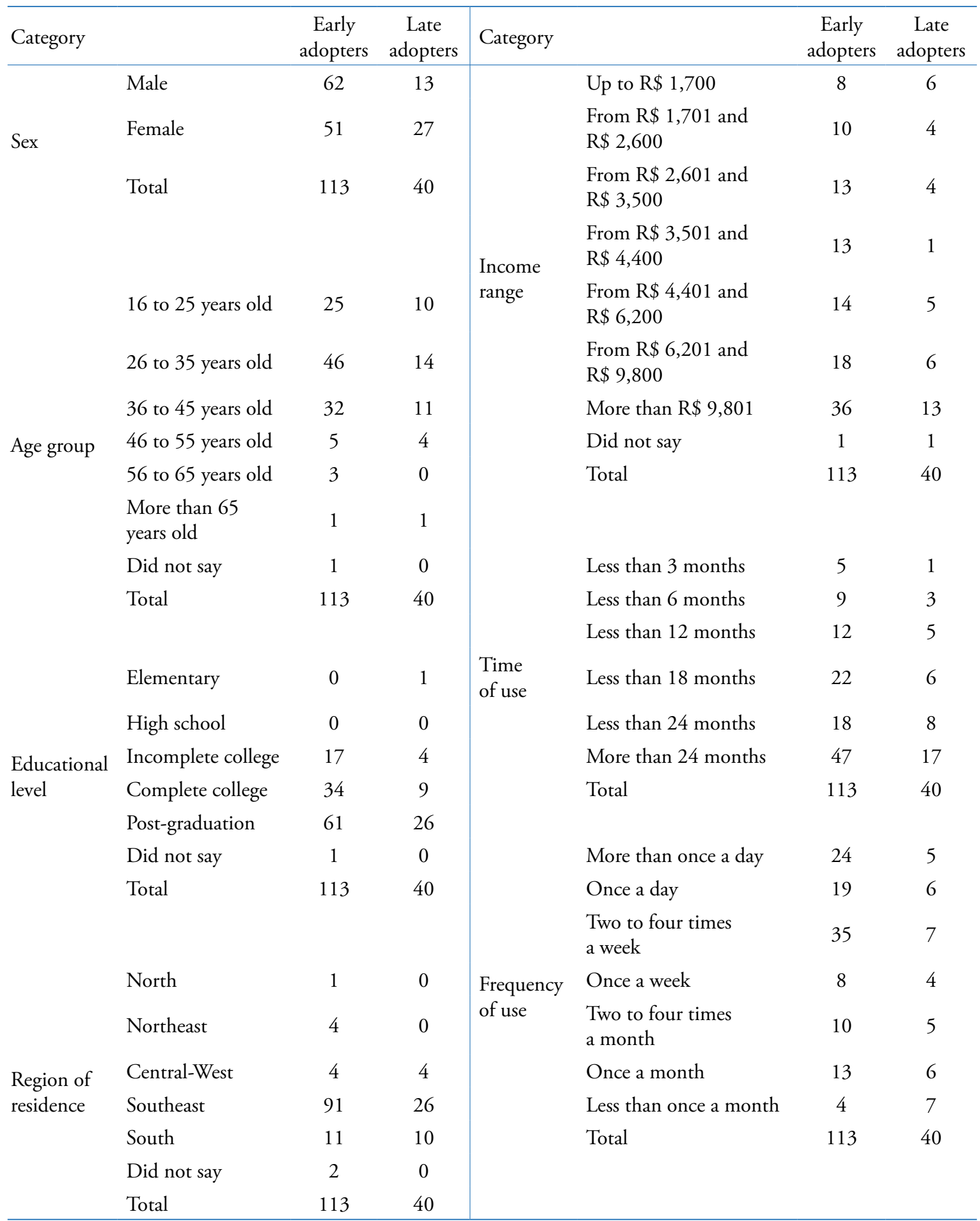


Table 9

Path coefficients

\begin{tabular}{lccccccccccc}
\hline & \multicolumn{4}{c}{ Total Sample $(\mathrm{n}=155)$} & \multicolumn{4}{c}{ Early Adopters $(\mathrm{n}=113)$} & \multicolumn{5}{c}{ Late Adopters $(\mathrm{n}=40)$} \\
$\mathrm{Path}$ & $\beta$ & $\mathrm{t}$ & $\mathrm{p}$-value & $\beta$ & $\mathrm{t}$ & $\mathrm{p}$-value & $\mathrm{R}^{2}$ & $\beta$ & $\mathrm{t}$ & $\mathrm{p}$-value & $\mathrm{R}^{2}$ \\
\hline $\mathrm{PB} \rightarrow \mathrm{CI}$ & 0,850 & 16,156 & 0,000 & 0,818 & 17,118 & 0,000 & 0,729 & 0,813 & 5,883 & 0,000 & 0,796 \\
$\mathrm{PR} \rightarrow \mathrm{CI}$ & $-0,050$ & $0,836 \mathrm{~ns}$ & 0,403 & $-0,067$ & $1,334 \mathrm{~ns}$ & 0,317 & & $-0,113$ & $0,687 \mathrm{~ns}$ & 0,492 & \\
\hline $\mathrm{EB} \rightarrow \mathrm{PB}$ & 0,262 & 3,260 & 0,001 & 0,412 & 4,099 & 0,001 & 0,682 & $-0,007$ & $0,044 \mathrm{~ns}$ & 0,965 & 0,847 \\
$\mathrm{ST} \rightarrow \mathrm{PB}$ & 0,297 & 3,891 & 0,000 & 0,218 & 2,358 & 0,000 & & 0,539 & 3,594 & 0,000 & \\
$\mathrm{CV} \rightarrow \mathrm{PB}$ & 0,387 & 4,729 & 0,000 & 0,295 & 2,843 & 0,000 & & 0,410 & 3,160 & 0,002 & \\
\hline $\mathrm{FR} \rightarrow \mathrm{PR}$ & 0,383 & 5,214 & 0,000 & 0,343 & 4,308 & 0,000 & 0,598 & 0,467 & 2,900 & 0,004 & 0,725 \\
$\mathrm{LR} \rightarrow \mathrm{PR}$ & 0,187 & 3,284 & 0,001 & 0,220 & 3,187 & 0,002 & & 0,144 & $1,186 \mathrm{~ns}$ & 0,236 & \\
$\mathrm{SR} \rightarrow \mathrm{PR}$ & 0,054 & $0,763 \mathrm{~ns}$ & 0,445 & $-0,017$ & $0,202 \mathrm{~ns}$ & 0,469 & & 0,214 & $1,730 \mathrm{~ns}$ & 0,084 & \\
$\mathrm{OR} \rightarrow \mathrm{PR}$ & 0,334 & 4,958 & 0,000 & 0,378 & 4,722 & 0,000 & & 0,230 & $1,938 \mathrm{~ns}$ & 0,053 & \\
\hline
\end{tabular}

In both cases, the structural model has good explanatory power for the variance in the intention to continue using fintechs: $72.9 \%$ for early adopters and $79.6 \%$ for late adopters. For early adopters, the economic benefit, seamless transactions, and convenience factors explained $68.2 \%$ of the variance of the perceived benefit factor and, for late adopters, this number was $84.7 \%$. The perceived risk factors - financial risk, legal risk, security risk, and operational risk - explained $59.8 \%$ of the variance of this factor for early adopters and $72.5 \%$ for late adopters.

Both for early users $(\beta=0.818, \mathrm{p}<0.05)$ and for late users $(\beta=0.813, \mathrm{p}<0.05)$, perceived benefit was important for continuance intention. In both cases, however, perceived risk was not significant. For early adopters, the most important factor for explaining their perception of benefit was economic benefit $(\beta=0.412, \mathrm{p}<0.05)$. For late adopters, this factor was not significant, with seamless transactions being the most important factor $(\beta=0.539, \mathrm{p}<0.05)$.

In relation to perceived risk, the operational risk factor was the most important for the early adopters $(\beta=0.378, p<0.05)$. For the late adopters, the most relevant factor was financial risk ( $\beta=0.467, \mathrm{p}<0.05)$.

Finally, to statistically verify the difference between the different types of users, a multigroup PLS analysis (Qureshi \& Compeau, 2009) was carried out, the results of which are presented in Table 10.

A t-test was carried out to test the statistical significance of the differences between the two groups. In relation to perceived benefit, the difference between the two groups was not significant, thus rejecting H10. For perceived risk, the difference between the early adopters and late adopters was also not significant, thus also rejecting $\mathrm{H} 11$.

We can conclude that the only factor whose difference was statistically significant between the groups was economic benefit, which was important for early adopters and not significant for late adopters (difference in the path coefficient $=0.423, \mathrm{p}<0.05$ ).

The rejection of both hypotheses suggests that there is no difference in the effect of the perception of benefits or risks on the intention to continue using fintech services between early and late adopters. Another explanatory possibility for the absence of a difference between the groups, in relation to the perceptions of benefit and risk, may be the inability of the questions presented in the questionnaire to adequately differentiate the users between early and late adopters. 
BBR

18

18
Table 10

Multigroup PLS analysis

\begin{tabular}{lcccccc}
\hline & \multicolumn{2}{c}{ Early Adopters } & \multicolumn{2}{c}{ Late Adopters } & $\begin{array}{c}\text { Diff. Path } \\
\text { Coeff. }\end{array}$ & p-value \\
Path & $\beta$ & $\mathrm{t}$ & $\beta$ & $\mathrm{t}$ & & \\
\hline $\mathrm{PB} \rightarrow \mathrm{CI}$ & 0,824 & 16,151 & 0,836 & 6,811 & 0,012 & 0,523 \\
$\mathrm{PR} \rightarrow \mathrm{CI}$ & $-0,053$ & $1,060 \mathrm{~ns}$ & $-0,093$ & $0,631 \mathrm{~ns}$ & 0,040 & 0,393 \\
$\mathrm{~EB} \rightarrow \mathrm{PB}$ & 0,415 & 4,131 & $-0,008$ & $0,055 \mathrm{~ns}$ & 0,423 & 0,004 \\
$\mathrm{ST} \rightarrow \mathrm{PB}$ & 0,219 & 2,315 & 0,569 & 3,946 & 0,350 & 0,982 \\
$\mathrm{CV} \rightarrow \mathrm{PB}$ & 0,291 & 2,729 & 0,385 & 2,937 & 0,094 & 0,721 \\
$\mathrm{FR} \rightarrow \mathrm{PR}$ & 0,346 & 4,385 & 0,474 & 2,899 & 0,128 & 0,754 \\
$\mathrm{LR} \rightarrow \mathrm{PR}$ & 0,217 & 3,204 & 0,150 & $1,228 \mathrm{~ns}$ & 0,067 & 0,307 \\
$\mathrm{SR} \rightarrow \mathrm{PR}$ & $-0,010$ & $0,119 \mathrm{~ns}$ & 0,208 & $1,638 \mathrm{~ns}$ & 0,218 & 0,928 \\
$\mathrm{OR} \rightarrow \mathrm{PR}$ & 0,377 & 4,816 & 0,222 & $1,912 \mathrm{~ns}$ & 0,155 & 0,134 \\
\hline
\end{tabular}

\section{CONCLUSIONS AND CLOSING REMARKS}

\subsection{RESEARCH RESULTS}

The aim of this study was to analyze the influence of benefit and risk factors perceived by fintech users on their intention to continue using these services. Following the study conducted by Ryu (2018), a survey was conducted with fintech users to evaluate their perceptions in relation to perceived benefits and risks, and a model was created in order to identify those relationships.

Unlike in the findings of Ryu (2018), this study identified that fintech users living in Brazil do not appear to consider the perception of risk in their decision to continue using the services, giving more importance to the benefits that they obtain through their use. Also, unlike in the study by Ryu (2018), the separation between early adopters and late adopters did not show any difference in the importance that each group gives to these factors.

The only difference identified between the two groups was the importance given to the economic benefit factor by early adopters and its non-significance for late adopters. Perhaps the perception of financial benefits is one of the forces that drives people to adopt fintech services. Thus, a study is needed to identify which factors lead users to adopt this type of service.

In general, the perceived benefits that most influence the continuance intention for fintech services are economic benefits for early adopters and seamless transactions for late adopters. However, the convenience factor was shown to be important for both groups. Thus, it may be interesting for fintechs to highlight these benefits for their users to increase their customer retention levels.

In relation to the perceived risks, operational risk was identified as the most important for the early adopters and financial risk was considered the most important for the late adopters. Although perceived risk did not show significance for continuance intention, it may be important for fintechs to better inform their customers in relation to risk factors, in order to reduce the insecurity with regards to this and increase the intention of their users to continue using their services. 


\subsection{LiMiTATIONS}

One of the limitations of this study relates to the difficulty in reaching respondents that are

users of fintech services and from other federative units of Brazil. By using the snowball technique, which uses virtual relationship networks, we were limited to bubbles of regional concentrations, obtained by convenience and that were concentrated in the Southeast and South regions of the country. Moreover, the respondent public presented homogenous income and educational levels, as the research was divulged with more emphasis within the academic environment. The separation between different types of users, with one group (early adopters, $n=113$ ) being significantly larger than the other (late adopters, $n=40$ ) was, possibly, another limitation of the sample. With relation to the use of the 7-point Likert scale in this research, the respondents may have avoided using extreme answers or may have answered in a more neutral way (central tendency) in relation to more acceptable views, possibly resulting, however, in a biased analysis of the results.

\subsection{Future Studies}

For future studies, we recommend expanding research to other regions and to a public with a heterogeneous academic and income level, enabling a comparison of the data with this research, in order to form a more complete overview of fintech users in Brazil and of the factors that influence their continuity of use of this service. Moreover, the influence factors in this article have certain limitations, so it would be interesting for future studies to include other attitude factors, such as trust and brand image, as well as psychological factors and social norms.

\section{REFERENCES}

Barakat, A., \& Hussainey, K. (2013). Bank governance, regulation, supervision, and risk reporting: Evidence from operational risk disclosures in European banks. International Review of Financial Analysis, 30, 254-273.

Cervo, A. L., and Bervian, P. A. (1980). Metodologia cientifica. McGraw Hill.

Chishti, S. (2016). How peer to peer lending and crowdfunding drive the fintech revolution in the UK. In Banking beyond banks and money (pp. 55-68). Springer, Cham.

Davis, F. D., Bagozzi, R. P., and Warshaw, P. R. (1989). User acceptance of computer technology: a comparison of two theoretical models. Management science, 35(8), 982-1003.

Escobar-Rodríguez, T., \& Romero-Alonso, M. (2014). The acceptance of information technology innovations in hospitals: differences between early and late adopters. Behaviour \& Information Technology, 33(11), 1231-1243.

Fishbein, M., \& Ajzen, I. (1977). Belief, attitude, intention, and behavior: An introduction to theory and research. Addison-Wesley.

Fishbein, M., \& Ajzen, I. (1980). Understanding attitudes and predicting social behavior. Englewood Cliffs.

Forsythe, S., Liu, C., Shannon, D., \& Gardner, L. C. (2006). Development of a scale to measure the perceived benefits and risks of online shopping. Journal of interactive marketing, 20(2), 55-75.

Mundial, F. E. (2015). The Future of Financial Services: How disruptive innovations are reshaping the way financial services are structured, provisioned and consumed. Ginebra: FEM. http://www3. weforum. org/docs/wef_the_future_of_financial_services.pdf. 
freitas, H., Oliveira, M., Saccol, A. Z., \& Moscarola, J. (2000). O método de pesquisa survey. Revista de Administração da Universidade de São Paulo, 35(3).

Gangwar, H., Date, H., \& Ramaswamy, R. (2015). Understanding determinants of cloud computing adoption using an integrated TAM-TOE model. Journal of Enterprise Information Management, 28(1), 107-130. https://doi.org/10.1108/jeim-08-2013-0065.

Gerber, E. M., Hui, J. S., \& Kuo, P. Y. (2012, February). Crowdfunding: Why people are motivated to post and fund projects on crowdfunding platforms. In Proceedings of the International Workshop on Design, Influence, and Social Technologies: Techniques, Impacts and Ethics (Vol. 2, No. 11, p. 10). Northwestern University Evanston, IL.

Hair Jr, J. F., Hult, G. T. M., Ringle, C., \& Sarstedt, M. (2016). A primer on partial least squares structural equation modeling (PLS-SEM). Sage publications.

Halmenschlager, C. (2002). Um algoritmo para indução de árvores e regras de decisão. Porto Alegre. UFRGS. https://lume.ufrgs.br/bitstream/handle/10183/2755/000325797.pdf

Hong, W., \& Zhu, K. (2006). Migrating to internet-based e-commerce: Factors affecting e-commerce adoption and migration at the firm level. Information \& Management, 43(2), 204-221.

Jurison, J. (1995). The role of risk and return in information technology outsourcing decisions. Journal of Information Technology, 10(4), 239-247.

Kim, C., Mirusmonov, M., \& Lee, I. (2010). An empirical examination of factors influencing the intention to use mobile payment. Computers in Human Behavior, 26(3), 310-322.

Kim, Y., Park, Y. J., Choi, J., \& Yeon, J. (2016). The adoption of mobile payment services for "Fintech". International Journal of Applied Engineering Research, 11(2), 1058-1061.

Lee, D. K. C., \& TEO, G. S. Z. J. (2015). Emergence of FinTech and the LASIC Principles. Journal of Financial Perspectives, 3(3), 1.

Lee, M. C. (2009). Factors influencing the adoption of internet banking: An integration of TAM and TPB with perceived risk and perceived benefit. Electronic commerce research and applications, 8(3), 130-141.

Lee, E., \& Lee, B. (2012). Herding behavior in online P2P lending: An empirical investigation. Electronic Commerce Research and Applications, 11(5), 495-503.

Lee, I., \& Shin, Y. J. (2018). Fintech: Ecosystem, business models, investment decisions, and challenges. Business Horizons, 61(1), 35-46.

Lin, K. Y., Wang, Y. T., \& Huang, T. K. (2020). Exploring the antecedents of mobile payment service usage: Perspectives based on cost-benefit theory, perceived value, and social influences. Online Information Review, 44(1), 299-318. https://doi.org/10.1108/oir-05-2018-0175.

Mackenzie, A. (2015). The fintech revolution. London Business School Review, 26(3), 50-53.

Maroco, J. (2018). Análise Estatística com o SPSS Statistics. 7th ed. Report Number, Lda. Pêro Pinheiro.

Martins, C., Oliveira, T., \& Popovič, A. (2014). Understanding the Internet banking adoption: A unified theory of acceptance and use of technology and perceived risk application. International Journal of Information Management, 34(1), 1-13.

Okazaki, S., \& Mendez, F. (2013). Exploring convenience in mobile commerce: Moderating effects of gender. Computers in Human Behavior, 29(3), 1234-1242. 
Oliveira, S. V. W. B. D. (2004). Modelo para tomada de decisão na escolha de sistema de tratamento de esgoto sanitário (Doctoral dissertation, Universidade de São Paulo).

Peter, J. P., \& Tarpey Sr, L. X. (1975). A comparative analysis of three consumer decision strategies. Journal of consumer research, 2(1), 29-37.

Qureshi, I., \& Compeau, D. (2009). Assessing between-group differences in information systems research: a comparison of covariance-and component-based SEM. Mis Quarterly, 197-214.

Rahi, S., Mansour, M. M. O., Alghizzawi, M., \& Alnaser, F. M. (2019). Integration of UTAUT model in internet banking adoption context. Journal of Research in Interactive Marketing, 13(3), 411-435.

Rogers, E. (1983). Diffusion of innovations. Free Press, New York.

Ryu, H. S. (2018). What makes users willing or hesitant to use Fintech?: the moderating effect of user type. Industrial Management \& Data Systems, 118(3), 541-569.

Schierz, P. G., Schilke, O., \& Wirtz, B. W. (2010). Understanding consumer acceptance of mobile payment services: An empirical analysis. Electronic commerce research and applications, 9(3), 209-216.

Schwab, K. (2016). A Quarta Revolução Industrial. Edipro, São Paulo.

Sharma, S., \& Gutiérrez, J. A. (2010). An evaluation framework for viable business models for $\mathrm{m}$-commerce in the information technology sector. Electronic Markets, 20(1), 33-52.

Shawaqfeh, G. N. (2018). The Impact of E-Commerce on the Quality of Credit Facilities and Banking Services (Applied Study on Commercial Banks in Jordan). Academy of Accounting and Financial Studies Journal.

Zavolokina, L., Dolata, M., \& Schwabe, G. (2016). FinTech-What's in a Name? In: Thirty Seventh International Conference on Information Systems, Dublin, Ireland, 11 December 2016 - 14 December 2016.

Zavolokina, L., Dolata, M., \& Schwabe, G. (2016, December). FinTech transformation: How ITenabled innovations shape the financial sector. In FinanceCom 2016 (pp. 75-88). Springer, Cham.

\section{AUTHOR'S CONTRIBUTION}

The authors of this paper declare that they worked equally on the stages of conceptualization, investigation, methodology, project administration, supervision, validation, writing, and editing of this paper.

\section{CONFLICTS OF INTEREST}

All the authors of this paper declare that they have no type of conflict of interests in relation to the objects addressed in it. 